\title{
Viral infections, neonatal mortality and the mystery of the Athenian Agora: An interview with Professor of Anthropology Maria Liston
}

\author{
IOANNIS N. MAMMAS and DEMETRIOS A. SPANDIDOS \\ Department of Clinical Virology, School of Medicine, University of Crete, Heraklion 71003, Greece
}

Received July 18, 2017; Accepted August 22, 2017

DOI: $10.3892 / \mathrm{etm} .2017 .5010$

\begin{abstract}
Although excavated almost 80 years ago, the infants' 'bone well' of the Athenian Agora in Athens, Greece and its contents were never thoroughly evaluated and published, until only recently, when a re-analysis of the whole excavation findings was performed. The well dates back to the third quarter of the 2nd century BC and contained at least 449 infants. The project, which explored the causes of neonatal mortality, found that one-third of infants' deaths were attributed to neonatal meningitis, based on the presence of bone disposition on the endocranial surface of the studied skulls. Despite the non-specific differential diagnostic approach of this pathophysiological finding in neonates, the determination of the causes of neonatal mortality in the Athenian Agora is really an impressive scientific attempt and can be a valuable lesson to all neonatal and peadiatric health professionals. According to Professor Maria Liston, Associate Professor of Anthropology at the University of Waterloo in Canada, who was the principal investigator of the skeletons from the infants' 'bone well' of the Athenian Agora, neonatal meningitis was the most frequently detected cause of neonatal mortality. Viral diseases unquestionably contributed to neonatal mortality, she adds and highlights that further research is required in collaboration with physicians for the better understanding and interpretation of various archaeological findings related to neonatal mortality. In the context of the 3rd Workshop on Paediatric Virology, which will be held in October 7th, 2017 in Athens, Greece, Professor Liston will reveal the role of neonatal and paediatric viral infections in the Hellenic antiquity.
\end{abstract}

\section{Contents}

1. Introduction

2. The mystery of the Athenian Agora

Correspondence to: Professor Demetrios A. Spandidos, Department of Clinical Virology, School of Medicine, University of Crete, Heraklion 71003, Greece

E-mail: spandidos@spandidos.gr

Key words: Paediatric Virology, viral infections, neonatal mortality, Maria Liston
3. Questions and Answers

\section{Introduction}

In modern Neonatology, multidisciplinary neonatal teams strive to provide the highest quality of deserved care to the newborn babies $(1,2)$. Over the past 30 years, neonatal healthcare standards have enthusiastically been improved, and for this reason, neonatal mortality has declined substantially and continues to decrease. However, in several countries worldwide, the greatest risk of childhood death insists to occur during the neonatal period with about two-thirds of all neonatal deaths occurring during the first week of life, comparable to the Archaic, Classical and Hellenistic antiquity (3-5). Congenital, perinatal and neonatal infections, such as neonatal meningitis induced by specifically Group B Streptococcus, Escherichia coli and Listeria monocytogenes, continue to be included in the list of the principal direct causes of neonatal death (1). Of note, paediatric infectious diseases, including bacterial meningitis, are well described in the Hippocratic Corpus, a selection of notes, lectures and case reports gathered, compiled and preserved at the ancient library of Alexandria during the Hellenistic period in the middle of the 3rd century BC, while the surgical management of meningitis, as well as its complications have been reported accurately (6). Moreover, viral epidemic causes of neonatal morbidity and mortality, such as the Perynthos influenza-like pandemic, are also well documented in the Hippocratic Corpus (6). Despite the fact the viral diseases unquestionably have contributed to neonatal mortality in the Hellenic antiquity, to date their archaeological evidence remains limited.

Since the Minoan civilisation in Crete, as it was demonstrated by the analysis (7) of the remains of 144 skeletons in Kavousi, Crete, dated back to the 12th to 7th centuries BC, infants and children had equal access compared to adults to funerary treatment. In the world's largest infant cemetery on the west flank of the castle hill in Kylindra on the Island of Astypalaia in the southern Aegean Sea, between approximately the 8th century $\mathrm{BC}$ and the 1st century $\mathrm{AD}$, approximately 2,700 burials ranging from newborns of 24 weeks of gestation to children up to 3 years of age, were buried in large ceramic pots, amphorae or hydrias, following the common practice of the Archaic, Classical and Hellenistic period (8). Their measurements indicated that the great majority of infant 


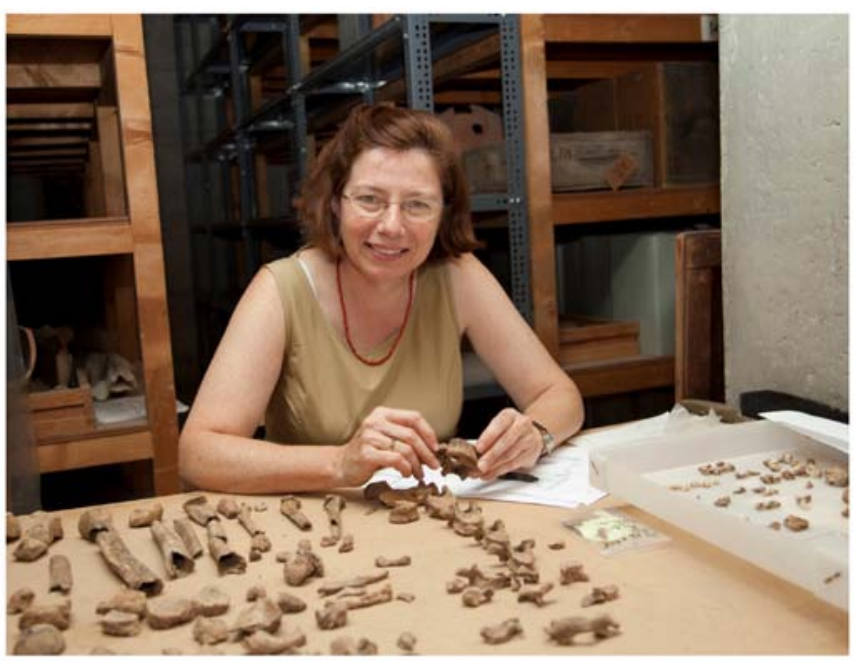

Figure 1. Professor Maria Liston, Associate Professor and Chair of the Anthropology Department at the University of Waterloo in Ontario, Canada at the American School of Classical Studies in Athens, Greece.

remains represented full-term babies dying around the time of birth, but some were much smaller, suggesting that they were born pre-term, and others were much larger, suggesting that they survived for at least a few months after birth. Recently, during the construction of the Stavros Niarchos Foundation Cultural Centre (SNFCC) in Faliro at the Aegean coast of Attica in Greece, between April 2012 and December 2013, in an area of approximately $3,000 \mathrm{~m}^{2}$, archaeological excavation revealed one of the most significant necropoleis in Attica, used from the late 8 th to the early 5 th century BC (9). Of note, out of a total of 1,069 excavated burials, 358 were pot burials, indicating burials of infants and young children. A similarly high proportion of infants' graves was found recently in the south part of the Island of Euboea at Aliveri, where the Classical cemetery of ancient Porthmos and Tamynai, belonging to the ancient city - state (polis - kratos) of Eretrians, was excavated from 2007 to 2013, during the construction of the new combined cycle Unit V of Aliveri Thermal Power Plant (Aliveri TPP) with natural gas fuel (10). However, during the Hellenistic period the representation of buried infants in cemeteries decreased significantly (11) and non-cemetery modes of disposal have been proposed to reflect an accepted regular practice at that time (12).

\section{The mystery of the Athenian Agora}

In the beginning of the last century, American archaeological excavation in Athens, Greece, revealed skeletons of 449 dead human infants along with 150 canine skeletons at the bottom of an abandoned stone-made well, partially lined with terracotta tiles (12-15). The infants' 'bone well' is located between the Athenian Agora, the civic and religious centre of the ancient city - state (polis - kratos) of the Athenians, and the Doric Temple of Hephaestus. It is approximately $1 \mathrm{~m}$ in diameter and more than $20 \mathrm{~m}$ in depth and is connected to a cistern and a collapsed water system constructed in the Classical period. Although excavated almost 80 years ago, - the initial estimation by the British-American biological anthropologist, John Lawrence Angel in 1945 was 175 infants - the well and its contents were never thoroughly evaluated and published, until only recently, when re-analysis of the whole excavation findings was performed by Professor Maria Liston (Fig. 1), a biological anthropologist at the University of Waterloo in Ontario (Canada) together with her colleagues Professor Susan Rotroff, a Classical archaeologist at the Washington University in St. Louis (MO, USA) and Dr Lynn Snyder, a zooarchaelogist at at the National Museum of Natural History of the Smithsonian Institution in Washington.

This surprising and disturbing finding is definitely unique in terms of the extraordinary number of dead babies found inside the well, the presence of their bones inside the walls of the city, not in practice during the Archaic, Classical and Hellenistic period, and the co-existence of canine sacrifices, a not infrequent finding associated with Athenian graves at that time (12-15). The initial main hypotheses attributed these findings either to the mortifying result of a mass infanticide, a practice, which in antiquity has been controversy proposed by several researchers (16), or to an undocumented plague epidemic or famine, perhaps associated with Lucius Cornelius Sulla's siege of Athens in $86 \mathrm{BC}$.

However, the recent detailed re-evaluation of the whole material of the well concluded that the deposits were much too earlier dating between 165 and $150 \mathrm{BC}$, at the end of Hellenistic period. The bones - the complete count of all identifiable infant bones was 12,808 - corresponded in size to skeletons ranging in age from 26 weeks in utero to 4 to 6 months post-term for the 2 older infants, with a clear peak at 37 to 38 weeks, or about the age of a full-term birth. What is of great interest is that all the infants, save three, were less than a week old at the time of death, appeared to have died naturally and not as part of some pandemic, while the presence of reactive endocranial bone deposition in the studied skulls (Fig. 2) proposed that as many as one-third died of neonatal meningitis. Despite the non-specific differential diagnostic approach of this pathophysiological finding in neonates $(17,18)$, the determination of the cause of neonatal deaths in the Athenian Agora highlighting the role of neonatal meningitis is really an impressive scientific attempt. Undoubtedly, this archaeological finding of our historical past is definitely touching; the final answer of the mystery can be a valuable lesson to all neonatal and paediatric health professionals.

Professor Maria Liston, AssociateProfessor of Anthropology and Chair of the Anthropology Department at the University of Waterloo in Ontario (Canada), received her BA in Classics from the King College in Bristol, Tennessee and her MA in Classics from Indiana University in the USA. She then completed her BA and her PhD in Anthropology at the University of Tennessee. She pursues research as a skeletal biologist and archaeologist, focusing on the excavation and analysis of human remains and their mortuary contexts. Since 2001, she has worked as the skeletal biologist in the Athenian Agora. In her work there, she has recently identified possibly the oldest case of battered child syndrome known from the archaeological record (19). She also works in Greece with the excavations at Mycenaean Iklaina, and the new excavations in the Sanctuary of Ismenion Apollo in Thebes. She is currently publishing the skeletons from tombs found at Kavousi, Crete (7). She also has directed the analysis of the remains of British and colonial soldiers at Fort William Henry, in New York (20). She involves students in research and 

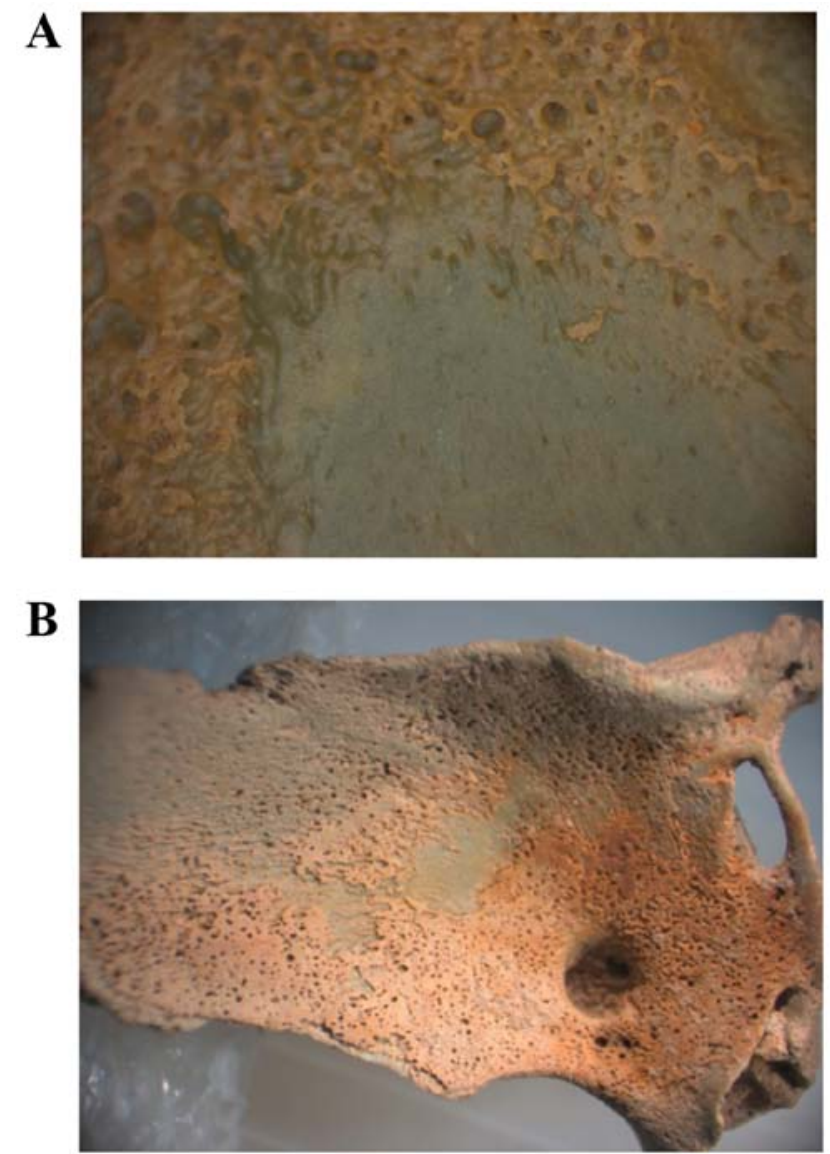

Figure 2. Reactive bone disposition on the endocranial surface of (A) an infant's occipital and (B) an infant's sphenoid of the 'bone well' of the Athenian Agora in Athens, Greece (images published with the permission of Professor Maria Liston). The copper staining from the well deposits can be seen on both bones. The copper from the water is taken up in the more mature underlying bone more than in the more newly formed bone, which really makes the new bone stand out. The presence of reactive endocranial bone deposition in the studied skulls of the infants of the 'bone well' in the Athenian Agora suggested that as many as one-third died of neonatal bacterial meningitis.

overseas study projects whenever possible. In the context of the 3rd Workshop on Paediatric Virology, which will be held in October 7th, 2017 in Athens, Greece (21), Professor Liston will give her key lecture on the causes and contexts of perinatal mortality in ancient Greece; she will reveal for the first time the role of neonatal and paediatric viral infections in the Hellenic antiquity and will light mysterious aspects of our secret past.

\section{Questions and Answers}

Question: Professor Maria Liston, first of all, congratulations for you scientific work; the determination of the cause of neonatal deaths in the Athenian Agora highlighting the role of neonatal meningitis is really an impressive attempt. We would like to ask you a few questions on the mystery of the Athenian Agora. How many exactly infants have been assumed to have died of neonatal meningitis and what were the meningitis signs that you detected on the skulls of the studied skeletons?

Answer: Approximately one-third of the occipital bones in the collection of infants showed signs of new endocranial bone deposition that are consistent with an endocranial infection. As I understand it, a bacterial infection is most likely to be the cause in infants this young. We are fairly confident that nearly all of the babies died before the ceremony called the Amphidromia, which would take place sometime around the 7th to 9th day of life. However, since there is no soft tissue and no blood to test, we can only assume that the new periosteal bone deposition is the result of bacteria instead of a viral cause. I was extremely conservative in counting infants with evidence of new bone deposition. There had to be a clear separate layer of new bone forming on top of a layer of normal bone. In many cases, there appeared to be pathological bone, but it was integrated into the underlying bone in such a way that it may have simply been normal rapidly growing bone. I did not count these individuals in my total. There were also lower numbers of parietal, temporal, frontal, and sphenoid bones that also had evidence of new bone formation on the endocranial surface. Those are not counted in the total either, as I cannot associate the various bones of individuals; there are too many infants of any given age to be able to identify individual skulls from the separate bones.

Question: Did you examine the presence of other infections, such as poliomyelitis or tuberculosis, also common causes of neonatal and paediatric death in antiquity?

Answer: As tuberculosis and poliomyelitis would probably have affected older children, not those less than 9 days old, I do not think that these infections are likely to be the cause of the new bone deposits in these very young infants. In addition, tuberculosis lesions on bone are almost exclusively lytic, instead of proliferative, and I am not aware that polio causes bone deposition in the skull. Thus, the evidence I have, supports a bacterial cause.

Question: Did you detect earlier infants skeletons, i.e., 4th or 5th BC, belonging to the Classical and not the Hellenistic period?

Answer: The infants in this deposit in the well are all associated with pottery that dates to the third quarter of the 2 nd century $\mathrm{BC}$, probably over a 15 -year span. Hellenistic and Roman pottery are not my specialty, but Professor Susan Rotroff, who did the analysis, probably knows more about Athenian pottery of that period than anyone living, and she has written many books and articles on the subject. So, we are confident of the date of the deposit. I have examined scattered infants from formal burials and other wells in the Agora, but most of those are much earlier, mostly Late Helladic and Early Iron Age. There were no cemeteries in the area of the Agora excavations after the early Iron Age, only a few bodies deposited in wells.

Question: How could you explain the co-existence of canine skeletons?

Answer: We believe the canine skeletons were sacrifices, probably done by the midwives, who were depositing the infants in the well. Dogs were sacrificed to remove ritual pollution, and both childbirth and untimely death were believed to be significant causes of pollution to the living. In addition, dogs were sometimes sacrificed to the goddess Hekate, who was involved with both childbirth and the passage of souls into and out of life. Thus, it is possible that some of them are dedications to Hekate. The age distribution of the dogs does not reflect the natural die-off that is seen in urban dogs in antiquity. Many of 
the dogs are young adults or older puppies, which normally are not represented in natural deaths in great numbers. Thus, we believe the dogs were being seised and killed, not just dumped in the well when they died of natural causes.

Question: The Hippocratic Corpus text has described several pandemics, such as the Perynthus influenza-like pandemic. Given that one-third of the babies died with the same findings and this occurred over only a 15-year span, what was your evidence to exclude a pandemic or even an epidemic?

Answer: It is clear that the infants in the well died from a variety of causes. Many of them were born early, and probably died from the many complications that result from premature birth. Others show evidence of bacterial infection on the endocranial surfaces. However, at least one-third of the infants died from causes we cannot identify precisely, or from a combination of causes. Viral diseases unquestionably contributed to the deaths, and seasonal or epidemic diseases such as influenza would have contributed. One important aspect of this deposit of infants in the well is that it gives us an unusually clear view of the variety of causes of perinatal mortality.

Question: You mentioned that the observed sign proposing neonatal meningitis as a cause of death was the endocranial new bone deposition. Could this deposition be an environmental or bacterial contamination?

Answer: The bones in this well exhibit unusually good preservation. This is due to the fact that the bodies of the infants remained under water for most or all of the time since they were deposited, and because there was a large quantity of bronze scrap also deposited in the well. The copper in the bronze has stained many of the bones, but also would have inhibited bacterial activity in the water, contributing to the good preservation. Due to the unusually good preservation, it is clear that there are deposits of new periosteal bone on the endocranial surfaces, instead of porosity caused by postmortem or taphonomic processes. In evaluating the bones for pathology, I only included pathologies in my count when there was a clearly identifiable layer of new bone deposited on top of more mature cortical bone. Simple porosity in the bone surface was not included in the count of pathological bone.

Question: As a skeletal biologist, how could you explain the pathophysiology of the formation of new bone deposition during the meningitis infection? How can inflammation of the meninges lead to new bone formation in a neonate?

Answer: Unfortunately, the exact mechanisms of bacterial or viral infections on endocranial bone have not been clearly described in medical literature in ways that can be applied to the study of dry bones. Understandably, physicians are more concerned with the effects on the soft tissues underlying the cranial bone, not the impact of infections on the bone itself. Paleopathologists have to start with visible bone symptoms and work backwards to aetiologies in the living individual. Sometimes the relationships are well documented in clinical and research literature, and sometimes they are not. It is likely that meningitis and periosteal bone reactions are both symptoms of either bacterial or viral infections in the cranium. Inflammation of the meninges, or potentially other tissues, is the clinically significant event. The activation of the periosteal membrane and the formation of new bone is less significant clinically, and unfortunately is rarely reported in autopsy studies. It would be very useful to paleopathologists if this phenomenon was studied through clinical and autopsy data, but there are naturally higher priorities in caring for the living patient. I would love to be able to answer this question, and I hope that sometime soon researchers, who have access to other types of data, might investigate this further. But for now, there are often significant gaps between changes we can document on the dry bone of archaeological specimens, and clinically oriented research. Skeletal biologists know much more about biology than ancient physicians, but sometimes it feels like we are almost as limited in our diagnoses as Hippocrates would have been struggling to explain disease through humoral medicine. It is why we need to work with physicians and medical researchers to better understand the pathophysiology of diseases.

Question: Thank you very much for your hospitality at the American School of Classical Studies in Athens, as well as your interesting answers lighting mysterious aspects of our historical past! We are looking forward to your key lecture at the 3rd Workshop on Paediatric Virology in October in Athens.

\section{References}

1. Greenough A, Osborne J and Sutherland S (eds): Congenital, Perinatal, and Neonatal Infections. Churchill Livingstone, London, UK, 1992.

2. Royal College of Paediatrics and Child Health: National Neonatal Audit Programme 2015 Annual Report on 2014 data. $\mathrm{RCPCH}, 2015$.

3. GBD 2013 Mortality and Causes of Death Collaborators: Global, regional, and national age-sex specific all-cause and cause-specific mortality for 240 causes of death, 1990-2013: A systematic analysis for the Global Burden of Disease Study 2013. Lancet 385: 117-171, 2015.

4. Malamitsi-Puchner A: Preterm birth in ancient Greece: A synopsis. J Matern Fetal Neonatal Med 30: 141-143, 2017.

5. Tzoumaka-Bakoula C, Lekea-Karanika V, Matsaniotis NS, McCarthy BJ and Golding J: Birthweight specific perinatal mortality in Greece. Acta Paediatr Scand 79: 47-51, 1990.

6. Mammas IN and Spandidos DA: Paediatric Virology in the Hippocratic Corpus (Review). Exp Ther Med 12: 541-549, 2016.

7. Liston MA: The human skeletal remains from Kavousi, Crete: A bioarchaeological analysis. $\mathrm{PhD}$ dissertation, University of Tennessee, Knoxville, TN, 1993.

8. Clement A, Hillson S and Michalaki-Kollia: The ancient cemeteries of Astypalaia, Greece. Archaeol Int 12: 17-21, 2009.

9. Stavros Niarchos Foundation Cultural Center (SNFCC): Archaeological findings. http://www.snfcc.org/construction/archaeological-findings.

10. Varela C: Cemetery of Classical Period in the site of Makria Rahi. The recent archaeological research in the area of Aliveri (2007-2013). Municipality of Kyme-Aliveri, Nov 9, 2013.

11. Lagia A: Notions of childhood in the classical polis: Evidence from the bioarchaelogical record. In: Constructions of Childhood in Ancient Greece and Italy. Cohen A and Rutter JB (eds). Hesperia Suppl 41. ASCSA Publications, Princeton, pp293-306, 2007.

12. Liston MA and Rotroff SI: Babies in the well: Archaeological evidence for newborn disposal in Hellenistic Greece. In: The Oxford Handbook of Childhood and Education in the Classical World. Evans-Grubbs J, Parkin T and Bell R (eds), pp62-81, 2013.

13. Liston MA: Murder in the Agora: Violent Death and Illicit Burial in Ancient Athens. The Canadian Institute in Greece, Jan 25, 2017.

14. Little LM: Babies in well G5:3: Preliminary results and future analysis. Am J Archaeol 103: 284, 1999. 
15. Papadopoulos JK: Skeletons in wells: Towards an archaelogy of social exclusion in the ancient Greek world. In: Madness, Disability and Social Exclusion: The Archaeology and Anthropology of 'Difference'. Hubert J (ed). Routledge, London, pp96-118, 2000.

16. Obladen M: From right to sin: Laws on infanticide in antiquity. Neonatology 109: 56-61, 2016.

17. Buckley HR: Subadult health and disease in prehistoric Tonga, Polynesia. Am J Phys Anthropol 113: 481-505, 2000.

18. Schultz M: Paleohistopathology of bone: A new approach to the study of ancient diseases. Am J Phys Anthropol 116 (Suppl 33): 106-147, 2001
19. Liston MA: The antiquity of child abuse: A case of battered child syndrome from the Agora of Athens. Am J Phys Anthropol 153: 170, 2014.

20. Liston MA and Baker BJ: Reconstructing the massacre at Fort William Henry, New York. Int J Osteoarchaeol 6: 28-41, 1996.

21. Mammas IN and Spandidos DA: Athens-based meeting to discuss the paediatric virology crossroad in October 2017. Acta Paediatr 106: 1536, 2017. 